\title{
The Effectivity of Therapeutic Communication on Pre- Surgery Education of The Implementation of Phacoemulsification technique Cataract Surgery With Local Anesthesia
}

\author{
Diyah Arini ${ }^{1}$, Christina Yuliastuti ${ }^{2}$, Aziza Nafi ${ }^{3}$ \\ ${ }^{1}$ Program Studi D3 Keperawatan, STIKes Hang Tuah Surabaya, Indonesia \\ ${ }^{2}$ Program Studi S1 Keperawatan, STIKes Hang Tuah Surabaya, Indonesia \\ ${ }^{3}$ RSMM Jawa Timur, Indonesia \\ 1diyaharini76@yahoo.co.id, ${ }^{2}$ chris.yulia@gmail.com, ${ }^{3}$ aziza.navi28@gmail.com
}

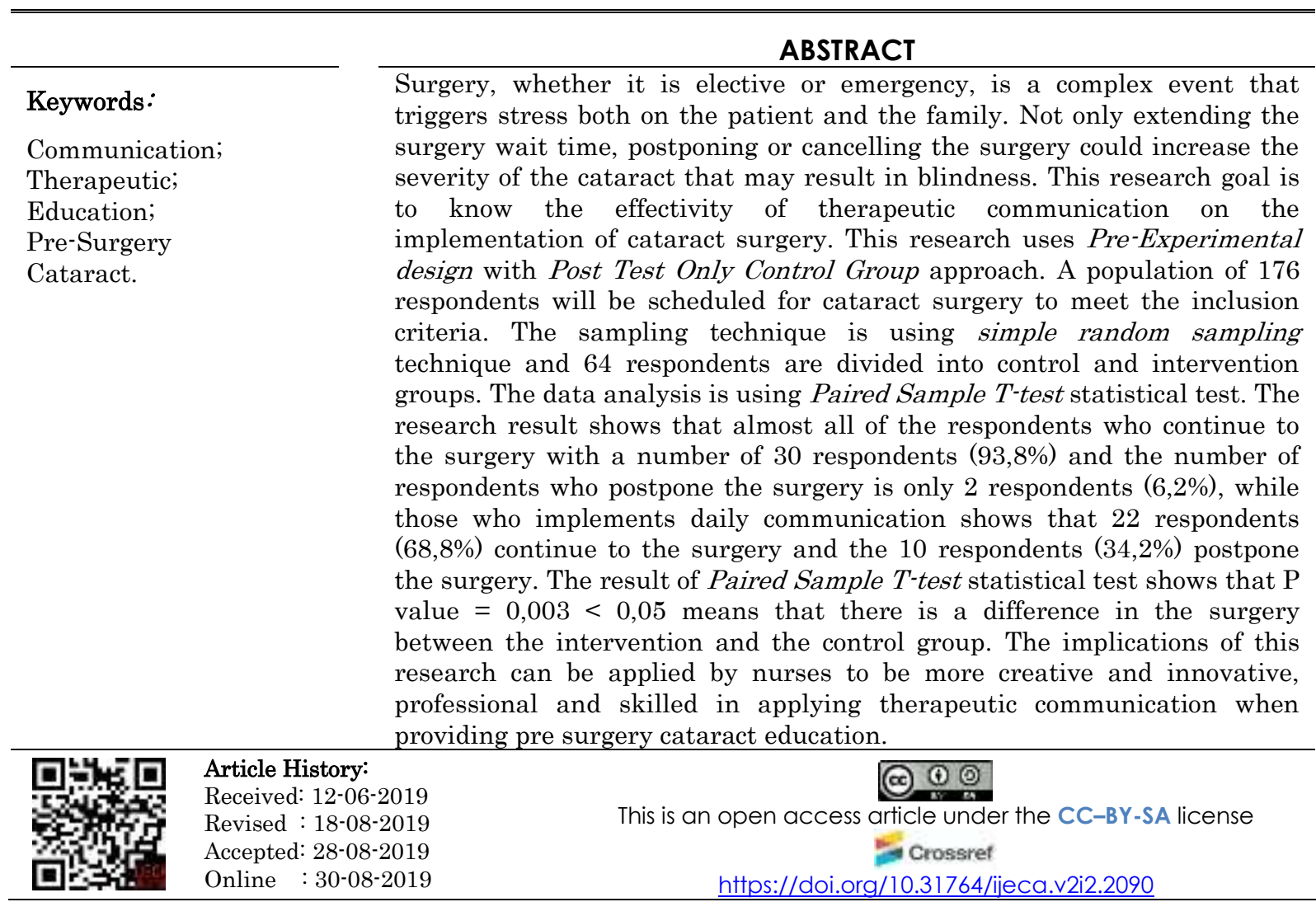

\section{A. INTRODUCTION}

Cataract is a muddiness condition on the eye lens that is caused by a hydration (lens fluid addition), denaturation of lens protein happens because of both. Cataract medication is a surgery, where the lens is replaced with afakia glasses, contact lens, or intraocular planted lens (Ilyas, 2010). The newest cataract surgery method is using Phacoemulsification technique, which is a technique that uses ultrasonic vibrator (laser), no sutures needed on the cornea and anterior sclera (Ilyas, 2010). On the pre surgery step, nursing action emphasizes on efforts to prepare the 
physical and psychological condition of the patient in handling the surgery. This phase starts with surgery scheduling which gives the information and education and also prepares the patient physically and psychologically so they are ready to do the surgery. Giving information and education to the family needs a professional communication skill. Therapeutic communication skill is important to identify and resolve the stress of the pre surgery patient (Batubara, 2015).

The phenomenon that happens in RSMM Jawa Timur, namely the implementation of pre surgery education, tends to lead to the fulfillment of routine nurse assignments without an interpersonal approach to reduce patient stress in response to surgery plans. So there is a lot of patients who postpone their surgery because of many factors, such as rapid nurse communication which does not giving any chance to ask; patient comes alone / no family support; feeling afraid to ask; decreased hearing function; decreased visual function; forget; other than that, the pre surgery information that is written in the surgery schedule card which are distributed to the patients has some weaknesses, such as letter are too small, compact writings, so the patients experience some difficulties in reading; health workers/patients is hasty. The leaflets are placed only at the information centre and not distributed to the cataract patients who is going to do a cataract surgery directly, so there are only a few patients who read the leaflet about cataract.

Some countries mention that there is still a lot of postponements and cancellation of elective surgery, $10-40 \%$ of the postponements of scheduled surgery happens because of various reasons. Based on RSUP Persahabatan in 2011, postponements that happen is mostly on surgical department $(29,7 \%)$, eye department $(9,7 \%)$ and lungs department $(6,7 \%)$. In other research of Srikantha (2014), reports that some factors that caused the cancellation of cataract surgery is eye problem (30,4\%) which consist of CSME (Clinically Significant Macular Edema), conjunctivitis, blepharitis, and iritis. While health problem $(29 \%)$ which consist of : active infections, systemic diseases and increased blood sugar (Srikantha, 2014).

The cause of surgical cancellation which both related to the hospital management and the patient's side is resulting in both material and moral losses, wasting time and resources that has been prepared, affecting on the decline of surgery room utilization that results in hospital disadvantage and also decreasing the patient's satisfaction. While for the patient's side, it gives an impact on the increase in cost incurred, eventually, surgical cancellation not only extend the surgery wait time but also increases the severity of the cataract that may result in blindness (Srikantha, 2014).

Pre surgery preparation is very important to reduce the risk factor, because the result of the surgery depends on the patient's condition. Surgical postponement risk factor on pre surgery patients can be reduced by increasing the role of the nurse as a health service team in giving the correct information and education about pre surgery preparation and increasing the good relationship between the nurse and the client by using therapeutic communication approach (Batubara, 2015).

The basic role of a nurse is to make sure that the physiological need of a patient is fulfilled. A nurse need to use their interpersonal communication skill to develop a relationship with the client as a whole human being. This therapeutic relationship will increase the psychological climate and fulfill the client's need (Tamsuri, 2014). Seeing the phenomenon, the writer is interested in doing a research on the effectivity of therapeutic communication on pre-surgery education of the implementation of PHACOEMULSIFICATION technique cataract surgery with local anesthesia at RSMM Jawa Timur. The data analysis is using Paired Sample T-test statistical test.

\section{B. METHODS}

This research uses Pre Experimental design, which is The Randomized Posttest Only Control Group Design. The population in this research is all of the patients who are scheduled to do a phacoemulsification technique cataract surgery with local anesthesia with as many as 64 respondents will be divided into two groups: 32 intervention groups and 32 control groups. The 
sampling technique that is used is Simple Random Sampling. The independent variable is therapeutic communication in pre surgery education and the dependent variable is the implementation of cataract surgery. The instrument is the observation assessment sheet of surgery implementation.

\section{RESULT AND DISCUSSION}

1. Intervention Group's Cataract Surgery Implementation on the pre surgery patients of Phacoemulsification Technique Surgery with local anesthesia at RSMM Jawa Timur

Table 1. Intervention Group's Cataract Surgery for Interventional Cataract Patients with Phacoemulsification Technique with Local Anesthesia in RSMM Jawa Timur

\begin{tabular}{lccc}
\hline \multicolumn{2}{c}{ Surgery Implementation } & Frequency (f) & Percentage (\%) \\
\hline Surgery & 30 & 93.8 \\
Postpone & 2 & 6.2 \\
\hline & Total & 32 & 100.0 \\
\hline
\end{tabular}

The Table 1 above shows the intervention group's surgery implementation as many as 30 respondents $(93,8 \%)$ do the surgery, while 2 other respondents $(6,2 \%)$ postpone their surgery. While the control group's surgery implementation as many as 21 respondents $(65,6 \%)$ do the surgery, while as many as 11 respondents $(34,4 \%)$ postpone their surgery.

2. Control Group's Cataract Surgery Implementation on the pre surgery patients of Phacoemulsification Technique Surgery with local anesthesia at RSMM Jawa Timur

Table 2. Control Group's Cataract Surgery for Interventional Cataract Patients with Phacoemulsification Technique with Local Anesthesia in RSMM Jawa Timur

\begin{tabular}{lccc}
\hline \multicolumn{2}{c}{ Surgery Implementation } & Frequency (f) & Percentage (\%) \\
\hline Surgery & 22 & 68.8 \\
Postpone & 11 & 31.2 \\
\hline & Total & 32 & 100.0 \\
\hline
\end{tabular}

The Table 2 above showsthe control group's surgery implementation as many as 21 respondents $(65,6 \%)$ do the surgery, while 11 other respondents $(34,4 \%)$ postpone their surgery.

3. The Effectivity of Therapeutic Communication On Pre-Surgery Education Of The Implementation Of PHACOEMULSIFICATION Technique Cataract Surgery With Local Anesthesia

Table 3. The Effectivity of Therapeutic Communication On Pre-Surgery Education Of The Implementation Of Phacoemulsification Technique Cataract Surgery With Local Anesthesia At RSMM Jawa Timur.

\begin{tabular}{ccccc}
\hline \multirow{2}{*}{$\begin{array}{c}\text { Surgery } \\
\text { Implementation }\end{array}$} & \multicolumn{2}{c}{ Intervention Group } & \multicolumn{2}{c}{ Control Group } \\
\cline { 2 - 5 } & Frequency (f) & Percentage (\%) & Frequency (f) & Percentage (\%) \\
\hline Surgery & 30 & 93.8 & 22 & 31.2 \\
Postpone & 2 & 6.2 & 11 & 68.8 \\
\hline Total & 32 & 100.0 & 32 & 100.0 \\
\hline & $\mathrm{p}=\operatorname{sig} 0.003$ & $<\mathrm{p}=0.05$ & & \\
\hline
\end{tabular}

The Table 3 above shows the result of the Paired Sample T-test statistical test that $\mathrm{p}=$ $0.003<\alpha=0.05$ means that there is a difference in the cataract surgery implementation 
between the intervention group and control group, or it can be interpreted that therapeutic communication is effective on the implementation of the Phacoemulsification technique cataract with local anesthesia pre surgeryeducation in RSMM Jawa Timur.

The research result shows the intervention group's surgery implementation as many as 32 respondents, which consists of 30 respondents $(93,8 \%)$ do the surgery, while 2 other respondents $(6,2 \%)$ postpone their surgery. Respondents who experiences postponement are caused by $530 \mathrm{mg} / \mathrm{dl}$ of Random Blood Sugar (GDA) and have not received their consultation approval from the internal disease specialist. According to the analysis result between the surgery implementation and the patient's disease history, the 2 respondents who experience postponement have a history of diabetes mellitus and have never done any cataract surgery before. Almost all of the intervention group as many as 30 respondents $(93,8 \%)$ who continue to the surgery can be related to some factors, such as education, surgical history, and family and religious supports. Factors that affect the implementation of cataract surgery are administration preparation, physical and psychological condition, and ophthalmology status. The pre surgery preparation is explained by the nurse in the surgical scheduling through the pre surgery education. The success of pre surgery education which consists of the medical information clarity to the patient depends on the ability to deliver message by an easily comprehensible communicator, beside that, information could be received and understood by the patient also depends on some subjective factors of the patient, such as the patient's education level where in the result of the research on intervention group shows that 1 respondent $(3,1 \%)$ is uneducated, 10 respondents $(31,2 \%)$ are elementary graduates, 11 respondents $(34,4 \%)$ are middle school graduates, 5 respondents $(15,6 \%)$ are high school graduates, and 5 respondents $(15,6 \%)$ are college graduates. Based on the frequency distribution results based on education level, as many as 21 respondents $(65,6 \%)$ are in middle school level or above. According to(Soekidjo Notoatmodjo, 2015)the higher the educational level of a person, it is easier for them to face a problem.

The intervention group's cataract surgical history shows as many as 11 respondents $(34,4 \%)$ had surgery before and 21 respondents $(65,6 \%)$ have not done any surgery. While on table 5.1, respondents with age of 45-59 years old are as many as 19 respondents $(59,4 \%)$. According to(Kozier, 2010) factors that affect the willingness of a patient in preparing for surgery depends on some factors, such as age, development status, experience or surgical history, lifestyle, injury, educational level, and the information distribution by the health worker. Pre surgery fear or anxiety is an anticipation response on an experience that can be considered a threat to the patient's role in life, self-integrity or even their own life. Patients who are facing a surgery covered in fear of nescience, death of anesthesia, anxiety of losing work time, and responsibility of supporting the family. Family is the main support system that will give direct treatment on every sick/healthy condition of a client. The role of a family in knowing health problem is the ability to take a decision in health, take care of sick family members, modify the surrounding and take the benefit of a health facility(Wibawa, 2014).

The result of the research of therapeutic communication on pre-surgery education of the implementation of Phacoemulsification technique cataract surgery with local anesthesia at RSMM Jawa Timur, shows that the intervention group's surgery implementation as many as 32 respondents, which consists of 30 respondents $(93,8 \%)$ do the surgery, while 2 other respondents $(6,2 \%)$ postpone their surgery. While in the control group's surgery implementation, respondents who applies daily communication as many as 21 respondents $(65,6 \%)$ and 11 respondents $(34,4 \%)$ postpone their surgery..

Based on the result of Paired Sample T-test statistical test, it shows the result that $\mathrm{P}=$ $0,003<\alpha=0,05$, thus there is a difference between the implementation of cataract surgery with therapeutic communication and with daily communication on cataract pre surgery education. 
Some things that need to be studied in pre surgery stage adapted from The Royal College of Ophthalmologist (2010) in Cataract Surgery Guidelines are the knowledge of surgical preparation, past experience, and psychological readiness. The pre surgery education that need to be given includes the explanation of various information in the surgical process. That information includes about the types of check-up before the surgery, certain tools that are needed, delivery to the surgery room, recovery room, and the possibility of medication after the surgery (Ophtalmologist, 2010).

In delivering pre surgery education, things that need to be considered is about time, according to a research, the education that is delivered in a long time before the surgery could result in the patient end up forgot about it, also if the time is too close to the surgery, the client will have no time to concentrate because of the anxiety, or there could be an effect of the medication before the surgery. According to (Kozier, 2010)five dimension of pre surgery counseling that can be identified important for the client, such as : Information, includes about what will be happen to the client, when, and what will be felt by the client, like sensation and inconveniences that will be experienced before, during, and after the surgery. Psychosocial supports to decrease the fear in the patient, the nurse is giving a support by being an active listener and giving an accurate information. Nurse needs to correct all of the client's perception mistakes like in the theory about therapeutic communication techniques according to (Aisah, 2015)such as carefully listening; showing acceptance; asking related questions; open question; repeating patient's message using their own words; clarifying; focusing; telling observation result; offering information; silence (maintaining tranquility); summarizing; giving rewards; offering themselves; giving the patient a chance to start a conversation; suggesting to continue the conversation; putting the events in order; giving the patient a chance to explain his/her perception; reflection, assertive, and humor. Nurses and doctors are giving a chance and also encourage the patient and family to actively ask and participate in taking decision about their medication, including giving informed consent.

The role of client and close related people is to know the information about pre surgery preparation, surgical procedures, and during the post-surgery phase. Client's comprehension about his/her role during the perioperative experience will increase the client's feeling of control and decrease anxiety or fear. If needed, clergyman can be invited to guide the patient to pray before the surgery. Skills Training, includes movements, deep breaths, coughs, support the incision wound with a pillow or hand, and using incentive spirometer. This is also in line with the result of other studies where it shows that there is an effect of pre surgery medical education on Hernia patients in RSUD Kudus to the effort that needs to be done so the patient's anxiety decreases and the surgery can be carried out (Kurniawan, 2013).

According to (Damayanti, 2014) the effectivity of therapeutic communication is determined by 5 aspects, which are: 1 . Openness, openness is very influential toward the effectivity of therapeutic communication. Open, in this definition is admitting that the feeling and thought that you said are actually yours and you are responsible for that; 2. Empathy, being sympathetic is feeling the others or feel sad too. While empathetic is feeling something as the one who experience it, being in the same situation and feeling the same feeling with the same method. Empathetic person can understand the motivation and experience of the others, their feeling and attitude, also their hope and wish for the future. We can communicate empathy both verbally and non-verbally. Non-verbally, we can communicate empathy with showing active contribution with that person through face expression and appropriate gestures, centered concentration includes eye contact, attentive posture, and physical closeness also appropriate touch or caress; 3 . Supportiveness, open and empathic communication cannot happen in a non-supportive situation. We show supportive attitude by being descriptive, spontaneous, and proportional; 4. Positiveness, in communicating positive attitude in interpersonal communication with at least 2 ways of showing positive attitude and positively encourage the person who is the interactive friend. Positive attitude refers to at least 2 aspects of interpersonal communication. That thing is in line with the research of Fitria, which shows that the nurse's interpersonal therapeutic communication can decrease 
the anxiety level of fracture pre surgery patient in hospital (Fitria, 2016); 5. Equality, in any situation, there could be any inequality. Regardless of this inequality, interpersonal communication will be more effective if the situation is equal. Means that there needs to be a silent acknowledgement that both of the parties are both valuable, and both of the parties have something important to donate (Fitria, 2016).

\section{CONCLUSION AND SUGGESTIONS}

There is a difference between the intervention and control group's implementation of cataract surgery, so the therapeutic communication on pre-surgery education proved effective to the implementation of Phacoemulsification technique cataract surgery with local anesthesia at RSMM Jawa Timur. Nurses who works in hospital should have an innovation to provide media to give an education that could be received by the patient and the family, especially the one that is suitable for cataract patients who are mostly elderly. For the next researcher, there needs to be a study about determinant analysis which causes the surgical postponement for cataract patients in hospital.

\section{ACKNOWLEDGEMENT}

Thank you for our institutions, STIKES Hang Tuah Surabaya, RSMM Jawa Timur that gave the support so this research could be done, also for the patients and families that are willing to be the respondents of this research.

\section{REFERENCES}

Aisah, S. (2015). Komunikasi dengan Empati, Informasi dan edukasi. Jakarta.

Batubara, I. (2015). Komunikasi Terapeutik pada Pasien Pre Operati Efektif Menurunkan Tingkat Kesemasan Pasien. Jurnal Ilmiah PANNMED, 9 No. 3, 250-252.

Damayanti, M. (2014). Komunikasi Terapiutik Dalam Praktek Keperawatan. Bandung: PT Refika Aditama.

Fitria, C. N. (2016). Efektifitas Komunikasi Terapitik Interpersonal Perawat terhadap Tingkat kecemasan PasienPre Operasi Fraktur. University Research Colloquium.

Ilyas, S. (2010). Ilmu Penyakit mata (ketiga). Jakarta: Universitas Indonesia.

Kozier, B. (2010). Buku Ajar Fundamental KeperawatanKonsep, Proses dan Praktik. (W. Dwi, Ed.) (7 vol. 1). Jakarta: EGC.

Kurniawan, A. (2013). Pengaruh Pendidikan Kesehatan Pre Operasi Terhadap tingkat kecemasan pada pasien Pre Operasi Hernia di RSUD Kudus. Jurnal Keperawatan, 6.

Ophtalmologist, T. R. C. of. (2010). Cataract Surgery Guidlines. London.

Soekidjo Notoatmodjo. (2015). Promosi kesehatandan Perilaku Kesehatan. Jakarta: Rineka Cipta.

Srikantha, N. (2014). Celebratting Best Conference : OnThe Day cataract Cancellation. London.

Tamsuri, A. (2014). Komunikasi Dalam Keperawatan. Jakarta: EGC.

Wibawa, S. R. (2014). Efektifitas Pemberian Edukasi Pre OperatifTerhadap kecemasan pada Pasien Pre Operasi Katarak di Jawa Tengah. Fakultas Kedokteran Universitas Gajah Mada. 